\title{
Business Strategy, the key determinants of SME growth in Kosovo
}

\author{
Enver Kutllovci, Venet Shala*, Burim Troni \\ University of Prishtina, Faculty of Economics, Kosovo. \\ *Corresponding Author: E-mail: venetshala@hotmail.com
}

\begin{abstract}
Small and medium enterprises (SMEs) are considered to be the engine of economic growth through employment generation, contribution to GDP, technological innovations and other aspects of economic and social development. SMEs are also important because they are key drivers of employment and economic growth. The growth of SMEs depends on ability of those firms to apply strategic management. In that context, strategic management is very important for small and medium enterpriese in the time of global competition, technological change and increased dynamics in markets. Even if many entrepreneurs do not formulate business plans, the strategic planning and systematic decision-making can be considered a key determinant of survival and success of small firms. The paper examines the relationship between strategic management and small and medium enterprises (SME) growth in terms of empirical analyses that include various strategic planning elements. The study has practical implications. Entrepreneurs need to be aware that strategic management practices, processes and techniques can be beneficial for growth of the firm. In order to enable their firms to grow, entrepreneurs may like to consider exactly formulating strategy, focusing on growth, profit, and market, among strategic analysis techniques paying special attention to analysis of market and competition and exactly formulating generic business strategies The key implication of this study for research is that the assessment of the relationship between strategic management and small firm growth needs to be done across various elements or dimensions.
\end{abstract}

Keywords: Growth, JEL Code: L25, M31, M10, Kosova, performance, SME, Strategic Management, Strategy.

\section{Introduction}

Given that the majority of research on strategic management has so far focused on large enterprises many scholars have recently noticed that there is a need to apply these concepts in the context of small businesses as well [1,2]. Strategy is the most important determinant of firm growth [3].Strategic management, ie strategy content and process (strategic planning) is widely considered to be one of the factors that contribute to small firm growth [4]. Studying strategic processes in growth-oriented firms therefore contributes to our understanding of the growth process which on the other hand bears broader economic relevance in terms of growth-oriented firms being amajor source of job creation $[5,6]$. However, not much is currently known about how small business managers actually perceive strategy and strategic planning, and thus what strategy actually means to them in their everyday business. Understanding the meaning of strategy in small enterprises is a prerequisite for detailed studies of how and what types of strategy making influence small firm performanceMany studies have recomended that business failure is due largely to an organization's failure to plan. As [7] noted,
"Without a clearly defined strategy, a business has no sustainable basis for creating and maintaining a competitive edge in the marketplace." This view is shared by various empirical studies that show a link between strategic planning and firm success [8, 9, and 10]. Strategic planning is therefore a very important research topic for organizational success. Studies have shown that the high failure rate among small firms, particularly among start-ups, can be attributed to the lack of formal business planning [11]. Studies have generally shown that planning is not only important for large organizations but for SMEs as well [12, 13] found that firms that plan produce better financial results than firms that do not plan. Lerner and Almor [14] contended that planning lays the groundwork for developing the strategic capabilities needed for high performance. Planning does not guarantee business success [15]. However, it is maintained that many of the contributing factors to business failures may be predicted and effectively address during the infancy of small business development when strategic planning is employed, thereby decreasing the failure rate for small business. 
Strategy can be formulated as an action performed by the firm in order to achieve its business objectives [16]. Strategy can be seen as a pathway to move a concept or an idea from the inventive state to the actual positioning in a competitive environment [17] or as a roadmap to the planned result. The role of strategy is to put the business theory in action and help the business to achieve desired results despite the environmental unpredictability. Strategy helps the business in the purposeful search for opportunities [18]. Overall strategy forms a basis for success of the firm [19]. Growth is a very important performance element and success measure in entrepreneurship. Our main thesis is that strategy is central and beneficial for business success of the firm in general, and for firm growth in particular. In past research, [20] found a positive relationship between strategic planning and firm profitability and growth.

\section{The development of SMEs in Kosovo}

Kosovo is one of the last countries in the region to start the transition process to establish a market economy.In this context, SMEs can play an increasingly essential role in this delayed transition trajectory, especially if we consider that tha private sector in Kosovo, consists almost entirely of SMEs (there are only a few large enterprises) For this reason, the SME sector's contribution is primarily evident in job creation and income growth. The increase in their number also contributes to the creation of a more competitive business environment. During the last ten years, in Kosovo was established a meaningful sector of SMEs. During the last three years there was a larger registration of the new businesses, in the early nineties and during the post war period, this has reflected the environment change for business in certain periods.

The spread of SMEs in Kosovo, according to the dynamics, can be viewed in three phases:

- First phase, from 1991 until 1993

- Second phase, from 1994 until 2000 and

- Third phase, from 2001

In the period between years 1991 until 1993 we have a rapid increase of the number of SMEs. In this period on annual average were registered around 5000 new enterprises.Private enterprises in Kosovo commenced establishing from 1989. However, the registration intensity of SMEs particularly started increasing after 1990 and it continued until 1995. At this time the enterprises were mainly organized in form of family economies, crafts, trade enterprises, small shops, restaurants, and agricultural enterprises. The establishment of these enterprises did not occur due to suitable business environment, but it occurred due to the necessity of creating new jobs for the people that were expelled from their working places in socially owned enterprises. These businesses were mainly established by own resources of Kosovo Diaspora.

\section{Data and Methodology}

The survey was disigned to study profile, trends, business planning, strategic issue and various constraints on the development and growth of SMEs. The sample includes SMEs across all regions of Kosova.In addition, all sectors of business activities are covered.The sample is stratified by there main sectors in order to reflect the differences between trade, production and services.Statistical stratification was done also in terms of size which includes micro enterprises, small enterprises and medium enterprises.All small and medium-sized firms included in the sample are defined in accordance to the EU definition ${ }^{1}$ The survey includes 51 SME in all Kosovo regions. The percentage of this sample from the population ensures sufficient significance on analyzing and identifying the situation and trend development of SMEs in Kosovo The interviews were conducted through the face-to-face method with the key people in each enterprises, mainly general managers.The respondents were asked to provide qualitative (their perceptions about the business environment and future prospect plans) and quantitative answer on internal characteristics of the respective firm (years in business, business strategies, location, size of the company in terms of employment, the sector of activity, strategic planning for the future, employment plans etc). Data processing was performed through Excel and STATA Aiming to have the most representative sample we have decided to stratify the sample according to: size, region and sectors.

\section{Research Findings}

\section{The Most Significant Strategies According to SMEs}

As it appears from data in the table 3, apparently the most preferred strategy in all sectors remains the strategy oriented towards improvement of products and services. This dominating strategy is shown to be focused in production sector with nearly $41 \%$, in services sector around $38 \%$, whilst in trade sector around $30 \%$. The second strategy stated by the majority of the enterprises is the

\footnotetext{
${ }^{1}$ Enterprises that employ less than 250 employees are considered SMEs (OECD and Europian Commission).Medium enterprises are considered those with 50-249 employees, small enterprises with $10^{-}$ 49 employees and micro enterprises up to 9 employees.
} 
Table 1:SME structure by size

SME Clasification

Micro-enterprises

Small Enterprises

Medium Enterprises

Big Enterpriseses

Total

Source: Minis

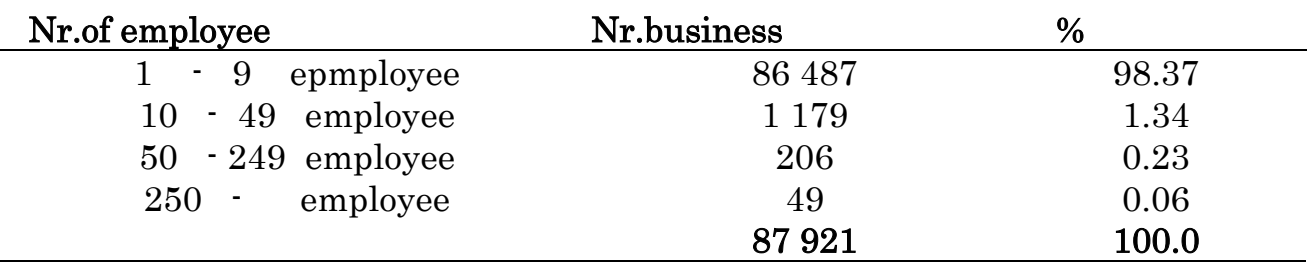

Table 2: SMEs strategy by sector $\%$

\begin{tabular}{lcccc}
\hline & Trade & Production & Services & Total \\
\hline $\begin{array}{l}\text { Quality improvement } \\
\text { of produc. and serv. }\end{array}$ & 29.41 & 41.18 & 37.93 & 34.02 \\
$\begin{array}{l}\text { Marketing } \\
\text { Advancement of }\end{array}$ & 21.57 & 11.76 & 20.69 & 19.59 \\
the main assets. & 5.88 & 5.88 & & 6.19 \\
Personnel training & & 17.65 & 17.24 & 20.62 \\
Cost decrease & 23.53 & 23.53 & 17.24 & 19.59 \\
Grand total: & 19.62 & 100.00 & 100.00 & 100.00 \\
\hline
\end{tabular}

Source: SME survey data: November 2009

Table 3: Do you have a written business plan?

\begin{tabular}{lllll}
\hline & Micro enterprises & Small enterprises & Medium enterprises & Grand total \\
\hline No & 68.97 & 41.18 & 40.00 & 56.86 \\
Yes & 31.03 & 58.82 & 60.00 & 43.14 \\
Grand total & 100.0 & 100.0 & 100.0 & 100.0 \\
\hline
\end{tabular}

Source: SME survey data, November 2009

Table 4: If you have a written business plan, how you use it

\begin{tabular}{llll} 
& Micro enterprises & Small enterprises & Medium enterprises \\
\hline For loan purposses & 60.0 & 36.4 & 0.0 \\
Strategic document & 27.6 & 63.6 & 100.0 \\
Other reasons & 3.4 & 0.0 & 0.0 \\
Grand total & 100.0 & 100.0 & 100.0 \\
\hline
\end{tabular}

Source: SME survey data, November 2009

Table 5: Strategic management and SME growth

\begin{tabular}{ll} 
& Growth of enterprise (\%) \\
Loan purposes & 28.44 \\
Strategic document & 64.52 \\
Other reasons & 7.04 \\
Grand total & 100.0 \\
\hline
\end{tabular}

Source: SME survey data, November, 2009

strategy concentrated in personnel training which is more dominating in trade sector and than in production and services.We may conclude out of this information that Kosovo businesses have been aware that the only way to expand their businesses as well as to be competitive in local market and later in international market is the most adjustable strategy to focus and invest on continuous quality improvement of the products and services. With this enterprises have confirmed that are tracking the new development dynamics of the global market which of course are being dominated by quantity, therefore the only strategy to be compatible with international businesses is to improve the quality of their products.The above table illustrates business sizes expressed in percentage that how many of them use the business plans for planning their strategies, and clearly we have expressed their percentages according to the chart shown for micro, small and medium enterprises. Within micro enterprises is shown that $68.97 \%$ of them do not use their business plan for their business activities which is understandable since these micro enterprises numerically have only one employee, on the other hand based upon the survey its around 31\% that are in possession of the business plans. This shows that the micro enterprises that do not possess business plans are the majority. As far as small businesses are concerned it appears that there is a higher percentage of those who use the business plan comparing to those who do not use the business plan which expressed in percentage is nearly $58.82 \%$ comparing with the small businesses that do not use the business plan which expressed in percentage is around $41.18 \%$. Similarly is shown in tables for medium enterprises where it can be seen that the percentage of those that possess business plans is higher than the ones that are not 
in possession of a written business plan, which shown in percentage is $60 \%$ possess written business plans, whereas $40 \%$ out of them do not possess written business plan. From the tables previously commented we have shown a division between the enterprises that use a written business plan and the enterprises that do not use a written business plan. While we argued regarding those that do not use the business plan, now in this table we will explain why these enterprises are using the business plan shown in categories according to their sizes: a) Loan application, b) as a strategic document, c) for other reasons. The information provided in above table has illustrated the numeric data of the companies that have used the business plans for intentions such as applying for loans and as a strategic document, whereas the table that will comment now it illustrates the percentages according to sizes of the enterprise which are divided as following: $3.4 \%$ of the micro enterprises use the business plan for loan application whereas $27.60 \%$ use the business plan as a strategic document whereas for other reasons only $3.40 \%$ use the business plan. The course of actions at small business varies where as shown in the table $36.4 \%$ of the enterprises use the business plan to apply for loan, whereas $63.6 \%$ use their business plan as a strategic document which shows that the comparison between micro enterprises and small enterprises is different related to usage of the business plan for loan application and as a strategic document, this shows that small business use more the business plan as a strategic document than for loan intentions, these changes the reality of action at business sizes where it is shown that medium enterprises use the business plan as a strategic document which expressed in percentage reaches up to $100 \%$ which shows that as bigger as the enterprise the strategies are more and more applied.

\section{Strategic Management and SME Performance}

As it appears from data in the table 6, enterprise performances have increased to most of the SMEs that use the strategic plan as a strategic document with around $65 \%$, whereas the enterprises that use the business plan only for loan purposes is around $28 \%$, and for other reasons have declared only $7 \%$.

\section{Conclusions and Implications}

From all of this that was discussed above, apparently Kosovo SMEs are playing an important role in economic development, and they continue to be the main source of creating the new jobs and generation of incomes as well as they show a rapid re- vitalization in the post-war period. The results of the SME survey show that there is a relationship between strategic planning and SME growth. The research finding show that Kosovo business have been aware that the only way to expand their business as well as to be competitive in local market and later in international market is the most adjustable strategy to focus and invest on continuous quality improvement of the products and services.From this we can conclude that SMEs in Kosovo are using the strategic plan as an orientation document for long-term development of their businesses, which means that they have a clear vision and mission where do they want to reach in a forthcoming period which usually includes parameters $3-5$ coming years. Currently there is an immediate need to assist in development of small and medium enterprises is a stronger institutional support, drafting a national strategy for SMEs, supplementing of legislation, financial support, business advices etc. Having into consideration the unsuitable situation of business operation in Kosovo as well as the lack of overall strategies, is very difficult to have a way out from this situation and it requires specific actions by focusing in the following activities:

- Creating and building strategies and development programs.

- Building a suitable environment for entrepreneurship and economic activities .

- Promotion of the appropriate locations for foreign investors and entrepreneurs.

- Support to SMEs.

- Promotion of local products and services.

- Ensuring access to capital.

- Development of various training forms for business.

- Cooperation among research institutions, businesses, and government.

Based upon this, it appears that in national level, the development of SMEs is defined with the lack of strategy either a mid-term or a long term in regards to private sector development. 


\section{References}

1. Perry SC (2001) The relationship between written business plans and failure of small business in the US. J. Small Business Management 39(3): 201-8.

2. Gibuson P, Kemp RG M (2005) Strategy and small business performance. Scientific Analysis of Entrepreneurship and SMEs.

3. Baker WHHL Addams, Davis B (2003) Business planning in successful small firms. Long Ragne Planning 26(6):82-8d.(1)

4. Baker G, Leidecker J (2001) Does it pay to plan? Strategic planning and financial performance. Agribusiness 17:355-64

5. Chaganti R (1987) Small business strategies in different industry growth environments. J. Small Business Management 25(3):61-8

6. Hitt RE Freeman, Hornsby JS (2005) Improving firm performance through strategy: The Academy of Management Executive MA.

7. Rhyne LC (1986) The relationship of strategic planning to financial performance. Strategic Management Journal 7(5):423-36.

8. Kraus S, Harms R, Schwarz E (2008) Strategic business planning and success in small firms. Int. J. Entrepreneurship and Innovation Management.

9. French SJ, Kelly SJ, Harrison JL (2004) The role of strategic planning in the performance of small, professional service firms a research note. J. Management Development, 23(9):765-76.

10.Golderb AI, Cohen G Fiegenbaum (2004) Small business strategies for successful venture development. J. Business Management.
11.Porter ME (2005) Toeards a dynamic theory of strategy. Strategic Management Journal.

12.Mintzberg H (1987) The strategy concept Iः Five Ps for strategy'. California Management Review 30(1):11-24.

13.Miller CC, Cardinal LB (2001) Strategic planning and firm performance Management Review 43 (Winter):139-60.

14.Miller CC, Cardinal LB (1994) Strategic planning and firm performance: A synthesis of more than two decaded of research. The Academy of Management Journal 37:1649-65.

15.MTI - Ministria e Tregtise dhe Industrise : Raporti per regjistrimin e bizneseve (2008).

16. Qeveria e Kosoves: Strategjia dhe Plani Zhvillimor i Kosoves (SPZHK) 2007-2013.

17.Stewart S (2002) Formal business planning and small business success: A survey of small businesses with an international focus. J. American Academ of Business Cambridge, Sep 2002.

18.Suzanne M Richbell, Doug Heats, Perry Eardle (2006) Owner-manager and business planning in the small firm. International Small Business Journal.

19.Simpson, DG (1998a) Why most strategic planning is a waste of time and what you can do about it part 1.”Long Range Planning 31(3):476 b-480.

20.White J (1998) Small and medium enterprise strategy a small business necessity, not a large firm luxury. Long Range Planning 31(6):813-14. 